\title{
Differences of Marital View between China and America in The Joy Luck Club under Cultural Dimensions Theory*
}

\author{
Huiqin Guo \\ Foreign Languages Department \\ Hubei University of Traditional Chinese Medicine \\ Wuhan, China
}

\begin{abstract}
The Joy Luck Club is a famous masterpiece made by a Chinese American female writer Amy Tan, which depicts four groups of immigrant mothers and their Americanraised daughters, and probes deeply into the psychological and emotional conflicts among four pairs of China-born mothers and American-born daughters when facing two different cultural backgrounds, also unveils the fierce conflicts of their marital views under different cultural ideology. Marriage as an essential part of women's life is also an important topic between Chinese and American cultural communication. Based on Hofstede's Cultural Dimensions Theory, this thesis explores the differences of martial view between China and America in The Joy Luck Club, which aims to deepen the understanding of differences of martial view between China and America in international communication.
\end{abstract} theory

Keywords-marital view; differences; cultural dimensions

\section{INTRODUCTION}

Amy Tan is a highly acclaimed Chinese-American female writer, who was born in Oakland, California in 1952. Adapting her brand of Chinese traditional talk story as a vehicle for exploring the lives of the mothers and daughters at the center of her novels, Tan allows readers to experience the lives of her characters from multiple perspectives in parallel and intersecting narratives. So far, Amy Tan has written a lot of works such as The Joy Luck Club, The Kitchen God's Wife, The Hundred Secret Senses, The Bonesetter's daughter, Saving Fish from Drowning, etc. with double identity and vivid perspectives, Amy Tan's works can easily show her writing talents, and through her works, readers can touch the sufferings of miserable people and make them to do some self-retrospection. All of those her great works makes her achieve success and gain a good reputation on Chinese-American literature.

With the publication of Amy Tan's first novel, The Joy Luck Club in 1989, which became the best-seller book for nine-month long, ranked the fourth in the best seller list in New York Times, and gained a lot of literary awards such as America Book Awards which set off a boom of Chinese

* Sponsored by Technology and Research Department of Hubei University of Traditional Chinese Medicine.
American literature, and then all of those pushed Amy Tan to become the new-born literary star in America overnight. In detail, this novel consists of sixteen related stories about the experiences of four Chinese American mother-daughter pairs In 1993, director Wayne Wang adapted the book into a film. Both book and film are deeply admired and appreciated among literary critics and readers. The film depicts the story from the perspective of women, mainly talks about the life changes of four women including Suyuan Woo, An-mei Hsu, Lindo Jong and Ying-ying St. Clair who lived in China at their young age, then moved to America and finally settled down there, and gave birth to their American-born daughters including Jin-mei Woo, Rose Hsu, Waverly Jong and Lena St. Clair. When Amy Tan explored the mother-daughter dyad, she recognized that the metaphor of umbilical relationship gets to extend with time going by, and makes this relationship becomes disconnect or develop to some extent: the first reason is because of individual, and the second is due to different culture. Therefore, it investigates the conflicts on culture and value among Chinese and American culture. In The Joy Luck club, this novel can be divided into four parts; there are four family stories, and the center of each part is from one family turning to another, and the center of a family is formed by spousal relationship. Spousal relationship as the most intimate and the longest human relations is the most basic relation in a family. What impressed audience most in this novel is that the relationship and marriage of those main female characters, and their marriages have many problems and lurk some unnoticeable crisis. As a matter of fact, China is affected by Confucianism but America is affected by Christian Thoughts resulting from the different attitudes on marriage between China and America. So, this paper starts with marital views between China and America, based on the novel The Joy Luck Club, and research on the differences of marital views between China and America by using Hofstede's cultural dimensions theory, which aims to help those people to avoid mistakes who participate in cross-culture relationships. 


\section{Miserable MARRIAGE OF FOUR MOTHERS IN CHINA}

\section{A. The Marriage of Suyuan Woo}

Before the novel The Joy Luck Club begins, Suyuan Woo has died of a brain aneurysm. Actually her life story is unfolded by her daughter named Jin-mei Woo, based on what she has already known about her mother's stories, some anecdotes from her father, and what the other members of the Joy Luck Club tell her. During the WWII, Suyuan Woo had a husband who was served as an officer in Chongqing, China. Having suffered from the Japanese invasion, Suyuan Woo casted her two twin baby daughters away reluctantly and got to know that her husband has died.

Later, she remarries and goes to America, and forms a new Joy Luck Club with three other Chinese female immigrants she met at church. She gives birth to another daughter called Jin-mei. In Suyuan Woo's marriage, what destroy her most are her two babies left in China. Under the war, she could do nothing even they are her daughters. She died with helplessness and regret as an end of her life and marriage.

\section{B. The Marriage of Lindo Jong}

In Chinese feudal society, Lindo's marriage was not chosen by her but forced by her family just like all normal women. When Lindo was only twelve years old, she was coerced to be the wife of a neighbor's young son called Huang Tyan $\mathrm{Yu}$ through the machinations of the matchmaker. After training for households by her mother-inlaw, she and Tyan-yu got married when she grew up to sixteen. She soon discerned that her husband was just a boy and had no sexual interest in her. Lindo started to take care of her husband as a little brother, yet her cruel mother-in-law expected Lindo to deliver a grandchild by restricting her and giving her no freedom.

Decided to get away from this unfortunate situation, Lindo observed the people carefully in the family and finally came up with a good plan to escape her marriage without shaming herself by telling a lie that she brought bad luck to her husband's family and the servant girl has pregnant a child owned to her husband.

Freed from her first tragic marriage, Lindo determined to move to America. She remarried a Chinese American man, Tin Jong, and has three children: sons Winston and Vincent, and daughter Waverly.

\section{The Marriage of An-Mei Hsu's Mother and Herself}

An-Mei's grandparents and other relatives during raised her in her early years in Ningbo after her widowed mother came to be a concubine of a middle-aged man in wealth after her first husband's death. An-mei has witnessed her mother's tragic marriage and her hopeless suicide in the household. An-Mei later immigrates to America, marries, and gives birth to seven children (four sons, three daughters). The youngest, a son named Bing, drowns at age four.

\section{The Marriage of Ying-ying St. Clair}

When Ying-Ying is a young girl, she is asked by her rich and conservative family that Chinese girls should be intelligent and gentle. Therefore, Ying-Ying marries Lin $\mathrm{Xiao}$ who is a winsome man without love, but she believes it is her fate. Her husband Lin Xiao is uncovered to have extramarital affairs with other women. When Ying-Ying finds she is pregnant, she decides to have an abortion and be a hermit with relatives lived in a small city in China. As ten years goes by, she become a tailor in a clothing store in Shanghai, where she meets Clifford St. Clair who courts Ying-Ying for four years, and she consents to marry him after hearing that her former husband Lin Xiao had died, which makes her decide to move on. Then, Ying-Ying gives birth to a daughter Lena, after immigrating to San Francisco with St. Clair. Ten years old as Lena is, Ying-Ying becomes pregnant again, but the baby boy dies because he is anencephalic. Ying-Ying is scared when she recognizes that Lena has inherited her negative behaviors and trapped herself in a marriage without love by owning a controlling husband.

\section{MARRIAGE OF FOUR DAUGHTERS IN AMERICA}

\section{A. The Marriage of Jin-mei Woo}

Jin-mei Woo is an unmarried writer who is eager to travel to China to meet the half-sisters she has never known. And she tried her best to figure out and understand her mother SuyuanWoo's marriage.

\section{B. The Marriage of Waverly Jong}

Waverly has a daughter, Shoshana, from her first marriage with Marvin who shows no duty and care to the family with laziness in her young age, and then she is engaged to her boyfriend Rich Schields. Rich loves Waverly and Shoshana freely and deeply enough, but he does not make sense the Chinese traditional culture, so, there are some awkward time in her family dinner such as it needs some soy sauce (Amy Tan, 1989:59) to advice the delicious food made by Waverly's mother but do not understand what modesty means in Chinese communication.

Just because of Rich's impolite behaviors, Waverly already knew what Lindo would do, how she would attack Rich, how she would criticize him. Waverly has never known love is so pure before meeting Rich and she was afraid that it would become sullied by her mother and "I wondered if perhaps my mother had poisoned my marriage.

\section{The Marriage of Rose Hsu Jordan}

Rose marries a doctor, Ted Jordan, who loves her but also wants to spite his snooty, racist mother. After a malpractice suit, Ted has a mid-life crisis and decides to leave Rose. Rose confides in her mother and An-mei tells her the story of her own childhood. When Ted comes for the divorce papers, Rose finds her voice and tells him that he can't just throw her out of his life, comparing herself to his garden, once so beloved, now unkempt and full of weeds. An-Mei tells her that Ted has been cheating on her, which Rose thinks is absurd, but she later discovers this to be true. 
She wants to hire a good lawyer and fight for possession of the house, which she eventually wins. This tragic marriage has struck Rose's spirit a lot.

\section{The Marriage of Lena St. Clair}

Lena's husband, Harold, is also her boss. He takes the credit for Lena's business and design ideas. He demands financial "equality" in their marriage. Lena is an associate while Harold is a partner, so he has a larger salary than she does. However, he insists that all household expenses be divided equally between them. Harold believes that by making everything equal, they can make their love equal as well. Lena feels frustrated and powerless. She is like her mother, like a ghost, and her mother wants to help her regain her spirit and stand up for herself.

\section{DIFFERENCES OF MARITAL VIEW BETWEEN CHINA AND AMERICA UNDER CULTURAL DIMENSIONS THEORY}

\section{A. Difference of Conjugal Purpose between Chinese and American under Masculinity versus Femininity}

Chinese and American culture conflict comes along in the process, and the mother-daughter conflicts are displayed specially in different ways of life because of disparate cultures. Due to different cultural ideology between China and America, there are different marital views in social life. In The Joy Luck Club, China-born mothers and Americanborn daughters holds different views about marriage. The four mothers all had been married to a Chinese man when they were in China at their young age. The conjugal purpose of them is almost to finish their duties to form a family, and gave birth to some babies, especially a son to continue the family line from social masculinity orientation. Also there is no tolerance for women in china who violate chastity because China is more inclined to masculinity than America based on Hofstede's Cultural Dimensions Theory. But when focusing on four daughters' marriage, gaining happiness by themselves is the most important thing through their lifetime no matter the wife or the husband.

Take Lindo and Waverly as an example, Lindo is coerced into a strange marriage because her husband is just a little boy, but she has no choice. The reason why her mother-inlaw would choose her was just because her appearance is good and could give this family a grandson. However, Waverly chooses to go to marriage again with Rich just because the only reason that they love each other. The impact that Chinese traditional culture makes to overseas Chinese and their offspring has become more and more vague. Although, Lindo is the mother of Waverly, but as Waverly is raised in America, so Lindo's opinion about her daughter's marriage has little influence on Waverly's final decision. Actually, the difference of conjugal purpose between Lindo and Waverly unveils the difference of conjugal purpose between China and America. Chinese women's marriage is like a besieged city without liberty and American women's marriage is more like a grand palace with liberty because in the beginning of the marriage, they hold total different purpose.

\section{B. Freedom of Choosing a Spouse under Long-term versus Short-term Orientation Dimension}

1) Influence of class in marriage: Spouse selection is the beginning of a marriage. Before the beginning of a marriage, men and women first meet each other by chance or by arrangement. Owing to the Chinese feudal social system, class has been the most important elements when a woman decides to marry a man since ancient times, and China is a typical long-term orientation country, men and women will take social class, family background and mate's appearance into account when they choose their marital partner because of they consider what their children will look like and how wealthy their children will be when they were got birth to. Yet America is a country with short-term feature, for they always determine to chase what gains themselves love and joy when they choose a life spouse and go to marriage without considering social class or family's suggestions.

In traditional Chinese culture, parents are entitled to arrange life, future and marriage for their kids who must be obedient and filial. In The Joy Luck Club, Lindo's first tragic marriage was arranged to marry a businessman's family when she was a little girl because her mother believed that after she marrying to that businessman's family, she would live a better life with being never worried about making a living. But this kind of arranged marriage with class was brimmed with problems, because Lindo had no right to speak for herself when meeting her mother-in-law's suppression. Nevertheless, Lindo had to obey what her mother-in-law asked for her to give birth to a baby for the family because from the long-term orientation, it was contributed to the development of the family. Therefore, even Lindo could not get pregnant with her little husband, she also dropped out an idea that using the servant girl's pregnancy to cheat the family that they had the family line to solve the problem and release her herself.

Conversely, Americans are more focused on current happiness due to the western thought of carpe diem. The short-term orientation guided them to enjoy love, marriage, and the happiness of pursuing self-value. Lena's husband is her superior, who is in the different class compared to her, but they get to marry each other just because they fall in love with each other with passion, there is nothing with class in their marriage. Even they own independent property and adopt Dutch treatment in daily life.

2) Influence of divorce in marriage: The divorce rate of America is high enough these years. But in Amy Tan's times, to get divorced is an action that rebels against orthodoxy. From the perspective of long-term and shortterm orientation by Hofstede, Americans are inclined to get short-term pleasure, yet Chinese go to the long-term perspective. In America, it is more open on the freedom of marriage than in China and no one would fuss about people have been divorced or not. Having been divorced is a normal thing that most of American women can accept. But 
in traditional Chinese culture, divorce is regarded as an unlucky thing.

In The Joy Luck Club, Rose and her husband Ted's marriage has come to an end. However, Rose cannot bear off the blow as well as her mother An-mei with total traditional Chinese marital views about divorce. Through Rose's twice yell, "You can't just pull me out of your life and throw me away" to her husband Ted and "Please don't tell me to save my marriage anymore, it's hard enough as it is" to her mother An-mei, readers can discern that Rose and her mother as two Chinese American women with Chinese traditional marital views would regard divorce as an ashamed thing that would influence Rose's later marriage. But Ted chooses to get married with another woman after getting divorced with Rose who just has one reason that is Ted does not love Rose anymore, and he decides to marry another woman he loves a lot and pursue short-term happiness. Therefore, the impact of divorce is more on Chinese than on Americans when choosing a spouse from Hofstede's cultural dimension theory.

\section{Conjugal Differences between Chinese and American under Individualism Versus Collectivism Orientation Dimension}

1) Strength of self-consciousness in marriage: Conjugal differences embody in every aspect of a marriage between Chinese and American. Due to different cultural background and social ideology, it is meaningful to use Hofstede's Cultural Dimensions Theory from Individualism versus Collectivism perspective to analyzes conjugal differences between Chinese and American. Strong collective family has a tight family link, and hold close family relationship. In China, collectivism is the mainstream of the society in anytime and anywhere and it is always put in front of Individualism. Family as a little community, husband and wife have duty to keep the family harmonious and share weal and woe when they live together. In a family, wives in a marriage play an important role in raise children and maintain her husband's dignity. Also, the value orientation of collectivism can be found in a marriage is that a wife will use the collective thought to deal with the conjugal problems in life and work, and hold the view that she herself and her husband should not be divided into two parts, she must be obedient, and she must follow her husband's arrangements. Even there are some secrets; it should be shared to each other without hesitation. And wives are more afraid of betrayal in marriage because of they are lack of sense of security and belonging in the family community if the husband betrays her.

In The Joy Luck Club, An-mei Hsu is a widow, then raped by a rich businessman Wu Qing and becomes his fourth concubine. But in her times, her family feels ashamed to her actions to become a concubine of a man because they have sex before getting married for them living in a collective traditional society. As An-mei's grandmother said, "Your own thoughts are so busy swimming inside that everything else gets pushed out." In the end, all kind of pressure made by her tragic marriage causes An-mei's suicide. Therefore, in Chinese traditional culture, the collective society has weakened wives' self-consciousness which embody that husbands are stronger in selfconsciousness, and control the destiny of his wife and family.

However, there are some differences in American society when discussing about strength of self-consciousness in marriage. Spouse in America are more inclined to strengthen individualism and pursue the development of individuality and the achievement of self-value, and they prolong their love through marriage without making children as their reasons to keep a broken marriage. In America, marriage is more like a pact; wife and husband are loyal to each other. Even the couple is get married, the wife and the husband pursue their private rooms to be their own and do not like to share everything in detail to each other.

Under Amy Tan's description, Rose Hsu and her husband Ted get a divorce, and feel confused just like in "dark frog". This kind of confusion actually comes from the mixture of orientation of collectivism and individualism because Rose herself is raised in America and owns the value of individualism which means she can face up to her divorce by herself under the help of psychiatrist, but in the meantime Rose cannot refuse what her mother imbue to her about Chinese collectivism. But Rose yells at her mother and says, "Please don't tell me to save my marriage anymore," In Chinese traditional culture, it can never been found that a daughter yells at a mother. But Rose finally determines to accept Ted's choice to get married to another woman due to Rose's self-consciousness influenced by American individual ideology.

2) Differences of status between husbands and wives in marriage: There is different cultural ideology which makes different marital view between China and America. In a marriage, the status between husband and wife is being hot discussed nowadays. In feudal China, the orientation of collectivism pushes wives to feel that they are inferior to their husbands in all degrees, as a matter of fact, if a woman comes to a marriage, she will sacrifice all herself to achieve her husband, all of those are totally regarded as the most basic norm in people's mind. More precisely, wives' lower family status can be discerned from what wives have held less rights in a family such as financial rights, emotional rights and child education than husbands. In The Joy Luck Club, this kind of inequality can be observed easily in Ying Ying St. Clair's marriage history. In her first marriage, she is arranged to marry to a businessman, and then she loves him but he shows his infidelity to their marriage again and again without any respect to his wife Ying Ying.

On the contrary, American marriage like Lena and her husband Harold has showed that Americans chase the equality of everything in marriage including family status. Just like what Lena said, "We are equals. I' m also smart. I have common sense"; "We keep the money things separate"; "We keeping the money things separate"; "We sign prenuptial agreement over things." Under Hofstede's individualism theory, family member has separate financial 
rights. Lena and Harold work in the same company, have independent salary, and can easily sit down calmly to discuss about their spousal problems. All that Lena's words depicts that the pursuit of American marriage is equal and respect under the orientation of Individualism.

\section{CONCLUSION}

Through probing into the novel The Joy Luck Club by Amy Tan, differences of martial view between China and America can be found clearly in four immigrant mothers with traditional Chinese martial view and their four American-raise daughters with modern American martial view. This paper aims to clarify the differences from the perspective of conjugal purpose, spouse selection and different situation the spouse stay after marriage which existed in Chinese and American society by using Masculinity versus Femininity Perspective, Power Distance Perspective and Individualism versus Collectivism Perspective in Hofstede's Cultural Dimensions Theory, also aims to help people under different culture to discern of differences of martial view between China and America and improve the better understanding of international marriage.

\section{REFERENCES}

[1] T.Amy, The Joy Luck Club. New York: Ivy Books,1989.

[2] C. Lihua and X. Man, "Analysis the gender conflicts of The Joy Luck Club ," Studies in Literature and Language,volVI, 2016, pp.101.

[3] H.Grice. Negotiation Identities:An Introduction to Asian American Women's Writing. Manchester, UK \& New York: Manchester University Press, 2002

[4] G.Hofstede, Culture's Consequences: Comparing Values, Behaviors, Institutions and Organizations across Nations. Shanghai: Shanghai Foreign Language Education Press, 2008,pp 7-9. 